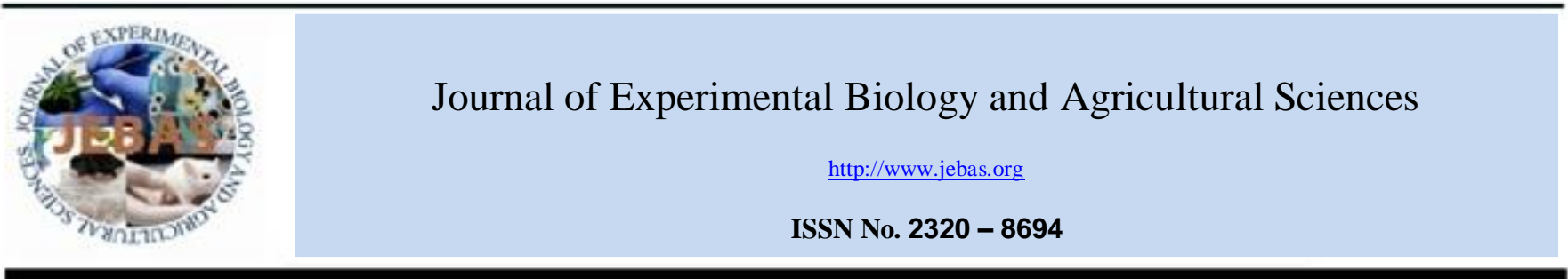

\title{
PERFORMANCE OF HYBRID MAIZE (Zea mays L.) IN DIFFERENT LEVELS AND TIME OF NITROGEN APPLICATION IN INDO-GANGETIC PLAINS OF EASTERN INDIA
}

\author{
Ankita Begam ${ }^{1}$, M. Ray ${ }^{1}$, D.C.Roy ${ }^{2}$, Sujit Adhikary ${ }^{3}$ \\ ${ }^{1}$ Department of Agronomy, Bidhan Chandra Krishi Viswavidyalaya, Mohanpur-741252, W.B \\ ${ }^{2}$ Department of LFC, West Bengal University of Animal \& Fishery Sciences, Mohanpur 741252 W.B \\ ${ }^{3}$ Agricultural and Ecological Research Unit, Indian Statistical Institute, Kolkata 700108 \\ Received - October 02, 2018; Revision - October 10, 2018; Accepted - November 25, 2018 \\ Available Online - December 15, 2018
}

DOI: http://dx.doi.org/10.18006/2018.6(6).929.935

KEYWORDS
Hybrid maize
Nitrogen level
Time of application
Yield
Seed index
B:C ratio

\begin{abstract}
Present experiment was conducted with four nitrogen levels $\left(75,100,125\right.$ and $\left.150 \mathrm{~kg} \mathrm{Nha}^{-1}\right)$ with three time of application viz. S1 ( $1 / 2$ as basal $+1 / 2$ at 25 DAS), S2 (1/2 as basal $+1 / 2$ at 45 DAS) and S3 (1/2 as basal $+1 / 4$ at $25 \mathrm{DAS}+1 / 4$ at 45 DAS) in split-plot design, during rainy season of 2016 and 2017 at Gayeshpur farm of B.C.K.V. Nadia, West Bengal, India on hybrid maize (P3377). Result of present study revealed that plant height increased with the increase of $\mathrm{N}$ level from 75 to $150 \mathrm{~kg} \mathrm{ha}^{-1}$. LAI and aerial dry matter accumulation were significantly higher at $125 \mathrm{~kg} \mathrm{~N}^{-1}$ and lowest in $75 \mathrm{~kg} \mathrm{~N} \mathrm{ha}^{-1}$ at harvest. Higher grain yield $\left(5.99 \mathrm{t} \mathrm{ha}^{-1}\right)$ and cob/plant, grain/cob, seed index and B:C ratio (1.75) were also obtained from $125 \mathrm{~kg} \mathrm{~N} \mathrm{ha}^{-1}$. Regarding time of application of $\mathrm{N}$, though treatment $\mathrm{S} 1$, exhibited higher plant height in the initial stage but ultimately treatment $\mathrm{S} 3$ recorded with better result. Higher grain yield of $5.63 \mathrm{t} \mathrm{ha}^{-1}$ and $\mathrm{B}: \mathrm{C}$ ratio (1.64) was obtained with $\mathrm{N}$ applied in thrice $(1 / 2$ as basal $+1 / 4$ at 25 DAS + 1/4 at 45 DAS) followed by S2. Thus from the pooled data of two years experiment it can be inferred that nitrogen level of $125 \mathrm{~kg} \mathrm{ha}^{-1}$ and applied in three growth stages $(1 / 2$ as basal $+1 / 4$ at 25 DAS $+1 / 4$ at 45 DAS) in maize can be used for yield increase and higher profit.
\end{abstract}

* Corresponding author

E-mail: dcroy09@gmail.com (D.C.Roy)

Peer review under responsibility of Journal of Experimental Biology and Agricultural Sciences.

Production and Hosting by Horizon Publisher India [HPI] (http://www.horizonpublisherindia.in/).

All rights reserved.
All the article published by Journal of Experimental Biology and Agricultural Sciences is licensed under a Creative Commons Attribution-NonCommercial 4.0 International License Based on a work at www.jebas.org.

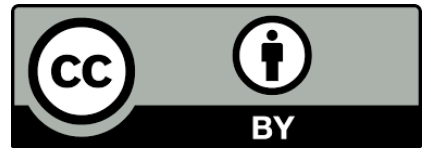




\section{Introduction}

Maize (Zea mays) is one of the most important cereal crops in the world agricultural economy both as a food source and raw material for animal feed. It is grown throughout the year because of its greater adaptability. In America and India, maize is referred to as corn which literally means "that which sustains life" (James 2001). It is grown with altitude ranges of 0 to 3000 meters above sea level (MSL). It has very high yield potential, there is no cereal which has so immense potentiality and in this reason it is called "queen of cereals". It is rank third among the cereals next to wheat and rice in the world (FAO 2018). Maize crop is utilized in many ways, green cobs are roasted and eaten by people with great interest and also several food dishes like chapattis are prepared out of maize flours and grains. Maize is also the sources of various industrial raw materials like glucose, starch, ethanol, synthetic rubber, dyes etc. Food and Agriculture Organization (FAO) predicts that an additional 60 million tons of maize grain will be needed from the annual global harvest by 2030 (FAO 2018). In indo gangetic area the main source of rainfall is the southwest monsoon and it is normally sufficient for agriculture in the rainy or monsoon season or kharif season. Indo-Gangetic plains comprises of both old and new Gangetic alluvial zones of states like Uttar Pradesh, Bihar, West Bengal, Jharkhand, Punjub etc. (Ray et al. 2014). In state West Bengal it spreads over full or partial coverage of eleven districts like Nadia, Murshidabad, North \& South 24 Paraganas, Howrah, Hoogly, East Midnapore, Burdwan, Birbhum, Malda and DakshinDinajpur. It has only $38 \%$ area of the state but contributes more than $80 \%$ of the state total food grains production (Ray et al. 2014). The climate of the region is dry humid, topography is flat, fertile loam or clayey loam soil with soil depth of 4-6 ft and good water holding capacity, $\mathrm{pH}$ nearly neutral and having annual rainfall of $1300-1600 \mathrm{~mm}$. The cropping sequences prevailing in this zone are mainly rice based cropping sequences like rice-rice, rice-potato-jute, rice-wheat-jute, rice-lentil-sesame, rice-rapeseed, mustard-sesame, rice-vegetable, etc. (Ray et al., 2009). Some cropping sequences need assured irrigation while others exist in rainfed condition. Mono cropping is rare in Indo-Gangetic plains of eastern India due to water or thermal limitation. Cropping intensity of this region is near about 250 percent (Ray et al., 2014).

Various experiments have been established that nitrogen played key role in maize production and the nitrogen requirement of maize is depend on weather conditions, soil type and crop rotation pattern (Plessis, 2003). Nutrient requirement is very high in case of maize crop because it is an exhaustive crop and its productivity closely depends on nutrient management particularly that of nitrogen. It plays a vital role for increasing the grain yield and their contribution is $40-50 \%$ (Begam et al., 2018). Splits application of nitrogen proved to be a best practice in sense that it reduced various losses and resulted to higher dry matter accumulation and growth of plant as compared to sole application as reported by many scientists (Haque et al., 2001; Harikrishna et al., 2005). Adequate nitrogen in maize plant not only affects the grain yield but also affects the quality of grains to a great extent. When application of nitrogen at low rates reduced grain yield of maize by $43-74 \%$ and number of grains per plant up to $33-65 \%$ (Andrea et al., 2006). With the increase in nitrogen dose, yield and protein concentration in maize seed increased. Yield of maize grain produced per unit of $\mathrm{N}$ fertilizer applied depends upon the uptake from fertilizer and soil $\mathrm{N}$ and its utilization. Nitrogen is taken up by maize plants throughout the season and it has the greatest need for nutrients during the tasseling, silking and grain formation stages, though relatively high nutrient concentration in the plant is necessary for maximum growth during vegetative growth period (Bundy, 2006). Application of nitrogen at the initial stage of the crop enhances the growth rate of leaf and root and ultimately it increases the yield of the crop. Therefore the experiment on different nitrogen levels and its time of application on hybrid maize was conducted with the objectives to determine the optimum level and appropriate time of application of nitrogen on hybrid maize in the Indo-Gangetic plains of eastern India.

\section{Materials and Methods}

The experiment was conducted at Gayeshpur farm, Bidhan Chandra Krishi Viswavidyalaya, Nadia, West Bengal, India situated at $23^{\circ} 8^{\prime} \mathrm{N}$ latitude and $89^{\circ} \mathrm{E}$ longitude with the altitude of 9.5 meters above the mean sea level (MSL) and topographically the land was medium in slope having well irrigation facility. The location of the experimental site belongs to sub-tropical humid climate with an average annual rainfall of $1460 \mathrm{~mm}$, mostly precipitated during June to September. The experiment was conducted during rainy season during 2016 and 2017 and variety was pioneer 3377.

The experiment was laid out in a Split Plot Design (SPD) with 3 replications and 12 treatments. Four main treatment comprising different nitrogen levels viz., M1 (75 kg N/ha), M2 (100 kg N/ha), M3 (125 kg N/ha), M4 (150 kg N/ha) were the in main plots and three time of $\mathrm{N}$ application, i.e. $\mathrm{S} 1(1 / 2$ as basal $+1 / 2$ at $25 \mathrm{DAS})$; S2 ( $1 / 2$ as basal $+1 / 2$ at 45 DAS); and S3 ( $1 / 2$ as basal $+1 / 4$ at 25 DAS $+1 / 4$ at 45 DAS) in sub plots respectively. The sub-plot size was 5 $\mathrm{m} \mathrm{X} 3 \mathrm{~m}\left(15 \mathrm{~m}^{2}\right)$. The whole experimental field was divided into 36 plots with 12 plots each for one replication. Channels are $1.5 \mathrm{~m}$ $\mathrm{X} 1 \mathrm{~m}$ border. Sowing of seed was done with a seed rate of $18 \mathrm{~kg}$ $\mathrm{ha}^{-1}$ to ensure desired plant population. Seed were sown manually at a distance of $60 \mathrm{~cm}$ row to row and $25 \mathrm{~cm}$ plant to plant at a depth of 3-5 cm. One irrigation was provided just after sowing of the seed for seed germination and another life saving irrigation was given at 20 DAS. Different growth parameters like plant height (canopy height), aerial dry matter accumulation and leaf 
area index (LAI) were recorded at 25 DAS (days after sowing), 50 DAS and at harvest. After harvesting the crop, grain yield and various yield attributes like cobs per plant, grains per cob, seed index or 100 seed weight etc. were determined. Economics of the crop in terms of Benefit - cost ratio then calculated by dividing the gross return by total cost of production. For statistical analysis of the recorded data and for determination of critical difference (CD) at $5 \%$ level of significance, the statistical formulae as laid down by Gomez \& Gomez (1984) were followed.

\section{Results and Discussion}

\subsection{Effect of Nitrogen fertilization of various growths attributes of hybrid maize}

Crop growth in terms of plant height of maize was progressively increased with the advancement of crop age starting from early stage to flowering of the crop and the height was steadily maintained up to near maturity in Indo-Gangetic plains of Eastern-India. A non-significant effect of various levels and time of application of nitrogen on plant height at 25 DAS was recorded. However, significant effect of different levels of nitrogen was observed both at 50 DAS and at harvest (90 DAS) and the maximum height (69.93 and 254.89 respectively) was recorded in M4 (i.e150 $\mathrm{kg} \mathrm{N} \mathrm{ha}^{-1}$ ) which was significantly higher over all the other nitrogen levels in both the cases. Similarly, highest plant height was obtained with $150 \mathrm{~kg} \mathrm{~N}^{-1}$ in baby corn in summer by Singh (2011). Similarly Thakur \& Sharma (2009) recorded the maximum height with $150 \mathrm{~kg} \mathrm{~N} \mathrm{ha}^{-1}$ in the same plant. At 50 DAS, significant effect of time of application of nitrogen on plant height was recorded and the highest value was observed in S1 plots (67.60) followed by S3 and the lowest in S2 (59.50). The probable reason behind the result might be that the S1 plots received full dose of $\mathrm{N}$ by 25 DAS whereas S3 plots received $75 \%$ and $\mathrm{S} 2$ received only $50 \%$ of full $\mathrm{N}$ levels within this period which helped faster growth of the plants. At harvest, time application of nitrogen on plant height was also found statistically significant and the higher plant height of $252.16 \mathrm{~cm}$ was recorded in S3 followed by S1 and S2 (table 1). The interaction effect of hybrid maize under different levels and time of application of nitrogen schedule was not found significant on plant height at different growth stages like 25 DAS, 50 DAS and at harvest. Amanullah (2007) reported that plant height of maize was significantly increased with the application of $180 \mathrm{~kg} \mathrm{~N}^{-1}$ as compared to 60 and $120 \mathrm{~kg} \mathrm{~N} \mathrm{ha}^{-1}$ at Peshawar (Pakistan). Increase in plant height with increasing nitrogen levels have been also reported by Muniswamy et al.(2007), Kumar (2009) and Parija (2011).

The values of aerial DMA (dry matter accumulation) increased continuously with the advancement of crop age and maximum values were recorded at harvest. The data in table 1 showed that different levels and time of application of nitrogen significantly influenced the aerial dry matter accumulation at only 50 DAS and at harvest in both main and sub plots whereas the said influence was not significant at 25 DAS in both cases. Amongst the different nitrogen levels (main plot), application of nitrogen at the rate $125 \mathrm{~kg} \mathrm{ha}^{-1}$ (M3) gave significantly highest dry matter accumulation of 269.14 and $821.22 \mathrm{~g} \mathrm{~m}^{-2}$ at 50 and at harvest respectively followed by M4 and M2. However, significantly lowest dry matter accumulation was recorded in treatment M1 i.e $\mathrm{N} @ 75 \mathrm{~kg} \mathrm{ha}^{-1}$. Regarding time of nitrogen application in the sub plots, higher aerial dry matter accumulation was observed in treatment $\mathrm{S} 1(1 / 2$ as basal $+1 / 2$ at 25 DAS) followed by S3 and S2 at 50 DAS. But at final growth stage (at harvest) significantly higher dry matter accumulation of $806.63 \mathrm{~g} \mathrm{~m}^{-2}$ was recorded in treatment S3 followed by S2 and S1. Interaction effect of different levels and time of application of nitrogen on aerial dry matter accumulation of maize was found statistically not significant at 25 and 50 DAS. However it was found significant at harvest and the better result $\left(851.09 \mathrm{~g} \mathrm{~m}^{-2}\right)$ was obtained from the treatment combination M3 X S3 (N @ $125 \mathrm{~kg}$ ha-1 with three split application of $\mathrm{N}$ at $1 / 2$ as basal $+1 / 4$ at 25 DAS $+1 / 4$ at 45 DAS) (Table 1). Two years field experiment was conducted by Joshi et al. (2014) during monsoon season on medium black soil at MP and observed highest dry matter (176.2 $\left.\mathrm{g} \mathrm{plant}^{-1}\right)$ with application of $100 \mathrm{~kg} \mathrm{~N} \mathrm{ha}^{-1}$ compare to 75 and $50 \mathrm{~kg}$ of $\mathrm{N} \mathrm{ha}^{-1}$ while, Aulakh et al. (2013) reported that higher dry matter accumulation (238 g plant $\left.^{-1}\right)$ at harvest was observed with the application of $175 \mathrm{~kg} \mathrm{ha}^{-1}$ of $\mathrm{N}$ compared to other levels of $\mathrm{N}\left(100,125\right.$ and $\left.150 \mathrm{~kg} \mathrm{ha}^{-1}\right)$ but it was statistically at par with $150 \mathrm{~kg} \mathrm{ha}^{-1}$ of $\mathrm{N}$ in loamy sand soils of Ludhiana in kharif season.

Recorded data showed that there is no difference in leaf area index at 25 DAS both in main plots and sub plots but it was found statistically significant at 50 and at harvest. Significantly higher LAI 2.05 (at 50 DAS) and 5.09 (at harvest/90 DAS) were recorded in 125 $\mathrm{kg} \mathrm{ha}^{-1}$ and they were at par with that of $150 \mathrm{~kg} \mathrm{~N} \mathrm{ha}^{-1}$ in both the growth stages. However lowest LAIs were obtained from $75 \mathrm{~kg} \mathrm{ha}^{-1}$ in both 50 DAS and at harvest or 90 DAS (table 1). Two years field experiment was conducted by Joshi et al. (2014) during kharif season in medium black clay soil and observed highest leaf area $\left(1261.4 \mathrm{~cm}^{2}\right)$ with application of $100 \mathrm{~kg} \mathrm{~N}^{-1}$ compared to 50 and $75 \mathrm{~kg} \mathrm{~N}^{-1}$. Regarding time of application of nitrogen, its effect on LAI on hybrid maize was statistically significant only at harvest. Better result on LAI (4.62) was recorded in treatment S3 ( $1 / 2$ as basal $+1 / 4$ at 25 DAS $+1 / 4$ at 45 DAS) though it was statistically at par with S2 and the lowest LAI (4.26) was recorded in S1. Regarding interaction effect on LAI, effect of different levels of nitrogen with its different time of application was found statistically significant only at harvest (Table 1). Among the different treatment combination better LAI (5.18) was obtained from the treatment combination M3 x S3(N@125 kg ha ${ }^{-1}$ with three split application of $N$ at $1 / 2$ as basal $+1 / 4$ at 25 DAS $+1 / 4$ at 45 DAS). 
Table 1 Different growth parameters of maize hybrid as influenced by levels and time of application of nitrogen (Pooled data of two years)

\begin{tabular}{|c|c|c|c|c|c|c|c|c|c|}
\hline \multirow[b]{2}{*}{ Treatment } & \multicolumn{3}{|c|}{ Plant height $(\mathrm{cm})$} & \multicolumn{3}{|c|}{ Dry matter accumulation $\left(\mathrm{g} \mathrm{m}^{-2}\right)$} & \multicolumn{3}{|c|}{ Leaf Area Index } \\
\hline & $\begin{array}{l}25 \\
\text { DAS }\end{array}$ & $\begin{array}{l}50 \\
\text { DAS }\end{array}$ & $\begin{array}{l}\text { At harvest/ } \\
90 \text { DAS }\end{array}$ & $\begin{array}{l}25 \\
\text { DAS }\end{array}$ & $\begin{array}{l}50 \\
\text { DAS }\end{array}$ & $\begin{array}{l}\text { At harvest/ } \\
90 \text { DAS }\end{array}$ & $\begin{array}{l}25 \\
\text { DAS }\end{array}$ & $\begin{array}{l}50 \\
\text { DAS }\end{array}$ & $\begin{array}{l}\text { At harvest/ } \\
90 \mathrm{DAS}\end{array}$ \\
\hline M1 & 27.09 & 58.55 & 232.18 & 37.59 & 248.50 & 750.03 & 0.82 & 1.55 & 3.96 \\
\hline M2 & 29.71 & 62.97 & 235.84 & 42.22 & 257.79 & 782.08 & 0.85 & 1.72 & 4.21 \\
\hline M3 & 29.42 & 65.14 & 238.73 & 39.66 & 269.14 & 821.22 & 0.87 & 2.05 & 5.09 \\
\hline M4 & 28.44 & 69.93 & 254.89 & 41.48 & 260.54 & 791.54 & 0.88 & 1.80 & 4.52 \\
\hline S.Em $( \pm)$ & 2.04 & 0.72 & 4.28 & 1.43 & 3.13 & 7.16 & 0.03 & 0.07 & 0.29 \\
\hline $\mathrm{CD}(\mathrm{p}=0.05)$ & NS & 2.41 & 14.39 & NS & 10.53 & 24.06 & NS & 0.25 & 0.99 \\
\hline S1 & 29.02 & 67.60 & 235.57 & 41.51 & 264.91 & 764.23 & 0.84 & 1.80 & 4.26 \\
\hline S2 & 28.19 & 59.50 & 233.50 & 40.20 & 252.62 & 787.79 & 0.85 & 1.76 & 4.46 \\
\hline S3 & 28.79 & 65.35 & 252.16 & 39.01 & 259.45 & 806.63 & 0.87 & 1.78 & 4.62 \\
\hline $\operatorname{S.Em}( \pm)$ & 0.79 & 0.76 & 4.01 & 1.38 & 3.01 & 5.02 & 0.03 & 0.03 & 0.11 \\
\hline $\mathrm{CD}(\mathrm{p}=0.05)$ & NS & 2.30 & 12.01 & NS & 9.01 & 15.02 & NS & NS & 0.32 \\
\hline \multicolumn{10}{|l|}{ Interaction } \\
\hline M1S1 & 28.52 & 62.14 & 222.64 & 39.3 & 251.68 & 730.06 & 0.81 & 1.56 & 3.68 \\
\hline M1S2 & 25.94 & 53.97 & 224.31 & 37.69 & 242.72 & 759.03 & 0.81 & 1.55 & 3.95 \\
\hline M1S3 & 26.81 & 59.54 & 249.58 & 35.77 & 251.11 & 761.00 & 0.83 & 1.54 & 4.24 \\
\hline $\mathrm{M} 2 \mathrm{~S} 1$ & 30.25 & 66.74 & 234.18 & 43.16 & 262.25 & 763.88 & 0.83 & 1.79 & 4.09 \\
\hline M2S2 & 29.27 & 57.14 & 227.24 & 42.14 & 252.52 & 784.91 & 0.84 & 1.62 & 4.17 \\
\hline M2S3 & 29.61 & 65.02 & 246.11 & 41.36 & 258.61 & 797.45 & 0.87 & 1.74 & 4.37 \\
\hline M3S1 & 28.12 & 67.64 & 235.88 & 41.02 & 277.80 & 800.74 & 0.87 & 2.12 & 4.99 \\
\hline M3S2 & 30.34 & 62.24 & 227.61 & 39.38 & 263.20 & 811.83 & 0.87 & 2.05 & 5.11 \\
\hline M3S3 & 29.81 & 65.54 & 252.71 & 38.57 & 266.42 & 851.09 & 0.87 & 1.99 & 5.18 \\
\hline M4S1 & 29.18 & 73.86 & 249.58 & 42.55 & 267.91 & 762.25 & 0.86 & 1.71 & 4.27 \\
\hline M4S2 & 27.21 & 64.65 & 254.85 & 41.57 & 252.05 & 795.38 & 0.87 & 1.83 & 4.60 \\
\hline M4S3 & 28.94 & 71.28 & 260.24 & 40.32 & 261.65 & 816.99 & 0.90 & 1.86 & 4.69 \\
\hline \multicolumn{10}{|l|}{$M \times S$} \\
\hline S.Em $( \pm)$ & 1.64 & 1.55 & 7.90 & 2.72 & 3.74 & 10.06 & 0.03 & 0.08 & 0.22 \\
\hline $\mathrm{CD}(\mathrm{p}=0.05)$ & NS & NS & NS & NS & NS & 30.07 & NS & NS & 0.64 \\
\hline \multicolumn{10}{|l|}{$\mathrm{S} \times \mathrm{M}$} \\
\hline S.Em $( \pm)$ & 2.61 & 1.43 & 7.71 & 3.12 & 4.05 & 10.66 & 0.04 & 0.09 & 0.21 \\
\hline $\mathrm{CD}(\mathrm{p}=0.05)$ & NS & NS & NS & NS & NS & 33.06 & NS & NS & 0.66 \\
\hline
\end{tabular}

Given data are the mean of three replicates and twelve treatments

\subsection{Effect of nitrogen on yield and yield attributes}

From the pooled data of two years experiment it was found that different nitrogen levels had significant effect on number of cobs per plant and the highest value (1.38) was recorded in $125 \mathrm{~kg} \mathrm{~N}^{-}$ ${ }^{1}$ (M3) though it was statistically at par with $150 \mathrm{~kg} \mathrm{~N} \mathrm{ha}^{-1}$ (M4) while treatment M1 recorded the least number (1.05) of cobs per plant (table 2). Recorded data also revealed that interaction effect of different levels of nitrogen with its different time of application did not significantly influence the number of cobs per plant though better result of 1.40 was obtained in M3 X S3 (N @ 125 $\mathrm{kg} \mathrm{ha}^{-1}$ with three split application of $\mathrm{N}$ as $1 / 2$ at basal $+1 / 4$ at 25 DAS + 1/4 at 45 DAS). Gahlout et al. (2010) reported that, the nitrogen levels did not showed any significant effect on number of cobs plant ${ }^{-1}$ of maize at Allahabad, U.P. 
Table 2 Yield attributes, yield and economics of maize hybrid as influenced by levels and time of application of nitrogen (Pooled data of two years)

\begin{tabular}{|c|c|c|c|c|c|}
\hline Treatment & No. of cob/plant & No. of Grains/cob & Seed index of 100 grain $(\mathrm{g})$ & Grain yield $\left(\mathrm{t} \mathrm{ha}^{-1}\right)$ & $\mathrm{B}: \mathrm{C}$ ratio \\
\hline M1 & 1.05 & 303.03 & 25.19 & 4.23 & 1.46 \\
\hline M2 & 1.22 & 331.74 & 25.28 & 5.27 & 1.48 \\
\hline M3 & 1.38 & 376.38 & 25.39 & 5.99 & 1.75 \\
\hline M4 & 1.36 & 349.66 & 25.36 & 5.78 & 1.66 \\
\hline S.Em ( $( \pm)$ & 0.06 & 8.27 & 0.77 & 0.13 & 0.09 \\
\hline $\mathrm{CD}(\mathrm{p}=0.05)$ & 0.21 & 27.78 & NS & 0.44 & 0.30 \\
\hline S1 & 1.22 & 323.59 & 25.28 & 4.90 & 1.51 \\
\hline S2 & 1.26 & 341.84 & 25.31 & 5.43 & 1.61 \\
\hline S3 & 1.29 & 355.19 & 25.33 & 5.63 & 1.64 \\
\hline S.Em $( \pm)$ & 0.07 & 9.45 & 0.92 & 0.16 & 0.15 \\
\hline $\mathrm{CD}(\mathrm{p}=0.05)$ & NS & 28.25 & NS & 0.47 & NS \\
\hline \multicolumn{6}{|l|}{ Interaction } \\
\hline M1S1 & 1.01 & 291.19 & 25.18 & 3.91 & 1.42 \\
\hline M1S2 & 1.05 & 300.67 & 25.19 & 4.18 & 1.47 \\
\hline M1S3 & 1.10 & 317.23 & 25.20 & 4.61 & 1.5 \\
\hline M2S1 & 1.16 & 316.29 & 25.30 & 4.56 & 1.41 \\
\hline M2S2 & 1.23 & 335.43 & 25.25 & 5.46 & 1.51 \\
\hline M2S3 & 1.27 & 343.5 & 25.29 & 5.80 & 1.52 \\
\hline M3S1 & 1.36 & 358.1 & 25.31 & 5.88 & 1.72 \\
\hline M3S2 & 1.39 & 376.68 & 25.41 & 5.99 & 1.75 \\
\hline M3S3 & 1.40 & 394.36 & 25.45 & 6.11 & 1.77 \\
\hline M4S1 & 1.34 & 328.76 & 25.31 & 5.23 & 1.50 \\
\hline M4S2 & 1.36 & 354.56 & 25.38 & 6.10 & 1.72 \\
\hline M4S3 & 1.37 & 365.66 & 25.39 & 6.01 & 1.75 \\
\hline \multicolumn{6}{|l|}{$\mathrm{M} \times \mathrm{S}$} \\
\hline S.Em $( \pm)$ & 0.08 & 12.04 & 1.07 & 0.26 & 0.31 \\
\hline $\mathrm{CD}(\mathrm{p}=0.05)$ & NS & 36.01 & NS & 0.78 & NS \\
\hline \multicolumn{6}{|l|}{$\mathrm{S} \times \mathrm{M}$} \\
\hline S.Em ( $( \pm)$ & 0.09 & 12.17 & 1.09 & 0.27 & 0.32 \\
\hline $\mathrm{CD}(\mathrm{p}=0.05)$ & NS & 37.72 & NS & 0.85 & NS \\
\hline
\end{tabular}

Given data are the mean of three replicates and twelve treatments

Various nitrogen levels significantly affected the number of grains per cob and it increases with the increase in nitrogen level up to $125 \mathrm{~kg} \mathrm{~N} \mathrm{ha}^{-1}$. Treatment M3 (125 $\left.\mathrm{kg} \mathrm{N} \mathrm{ha}^{-1}\right)$ yielded significantly higher number of grains per cob (376.38) though it was statistically at par with that of $150 \mathrm{~kg} \mathrm{~N} \mathrm{ha}^{-1}$ (M4). Similarly maximum grain per cob was obtained with $120 \mathrm{~kg} \mathrm{~N}^{-1}$ than that of with 60 and $90 \mathrm{~kg} \mathrm{~N} \mathrm{ha}^{-1}$ in baby corn by Pandey et al. (2010). Regarding the time of application of nitrogen significantly higher number of grains per cob (355.19) was obtained in S3 treatment (application of $\mathrm{N}$ as $1 / 2$ at basal $+1 / 4$ at 25 DAS $+1 / 4$ at 45 DAS) which was at par with $\mathrm{S} 2$ and significantly higher over the treatment S1. Interaction effect of levels and time of application of nitrogen on number of grains per cob was found statistically not significant (Table 2).

The data given in table 2 showed that different nitrogen levels as well as time of its application did not affect seed index of hybrid maize significantly. Application of nitrogen at different levels on 
hybrid maize had significant effect on grain yield. Among the different levels of nitrogen, application of $125 \mathrm{~kg} \mathrm{~N}^{-1}$ (M3) produced maximum grain yield $\left(5.99 \mathrm{t} \mathrm{ha}^{-1}\right)$ which was statistically at par with M4 i.e. application of $150 \mathrm{~kg} \mathrm{~N} \mathrm{ha}^{-1}(5.78 \mathrm{t}$ $\left.\mathrm{ha}^{-1}\right)$. Kaur (2016) reported the similar trend in hybrid maize while Sahoo \& Mahapatra (2014) revealed that increase in levels of nitrogen from 60 to $180 \mathrm{~kg} \mathrm{ha}^{-1}$ increased the grain yield of maize from 8.88 to $10.53 \mathrm{t} \mathrm{ha}^{-1}$. Similarly, the effect of different time of application of nitrogen on grain yield of hybrid maize was also found statistically significant in the sub plots. Maximum grain yield of $5.63 \mathrm{t} \mathrm{ha}^{-1}$ was recorded in treatment S3. Interaction effect of different levels and time of application of nitrogen on grain yield of maize was found statistically significant and the better result $\left(6.11 \mathrm{t} \mathrm{ha}^{-1}\right)$ was obtained from the treatment combination M3 x S3 (i.e N@ $125 \mathrm{~kg} \mathrm{ha}^{-1}$ with three split application of $\mathrm{N}$ as $1 / 2$ at basal $+1 / 4$ at 25 DAS $+1 / 4$ at 45 DAS) (table 2) probably due to higher number of cobs per plant, grains per cob and higher seed index.

\subsection{Effect of nitrogen on benefit cost $(B: C)$ ratio}

Effect of different nitrogen levels and their time of application on benefit cost ratio of hybrid maize was presented in table 2 and it was found that different nitrogen levels significantly influenced the benefit cost ratio but the effect was not significant in case of time of application of nitrogen. However, maximum benefit cost ratio of 1.75 was recorded with the application of $125 \mathrm{~kg} \mathrm{~N} \mathrm{ha}^{-1}$ which was at par with $150 \mathrm{~kg} \mathrm{~N} \mathrm{ha}^{-1}$ (1.66) but significantly better than $100 \mathrm{~kg} \mathrm{~N} \mathrm{ha}^{-1}(1.48)$ and $75 \mathrm{~kg} \mathrm{~N} \mathrm{ha}^{-1}$ (1.46). The results are in agreement with the findings of Kaur (2013). The interaction effect of different levels of nitrogen and time of application of nitrogen on benefit cost ratio of maize was also not significant.

Regarding the levels of nitrogen applied, higher benefit cost ratio of 1.75 was recorded from $125 \mathrm{~kg} \mathrm{~N}^{-1} \mathrm{~h}^{-1}$ though it was at par with $150 \mathrm{~kg} \mathrm{~N} \mathrm{ha}^{-1}$ (1.66) but significantly higher than $100 \mathrm{~kg} \mathrm{~N} \mathrm{ha}^{-1}$ (1.48) and $75 \mathrm{~kg} \mathrm{~N}$ ha $^{-1}$ (1.46). Kaur (2013) also reported the same trend in hybrid maize. However, the interaction effect of different levels and time of application of nitrogen on benefit cost ratio of hybrid maize was also not significant (table 2).

\section{Conclusion}

From the pooled data of two years of the experiment it can be concluded that growth parameters like plant height, aerial dry matter accumulation, leaf area index (LAI) significantly influenced by different levels and time of application of nitrogen. Plant height was increased with the increase of $\mathrm{N}$ level from 75 to $150 \mathrm{~kg} \mathrm{ha}^{-1}$ in all the growth stages. LAI and aerial dry matter accumulation remained not significant at 25 DAS but they were significantly higher at $125 \mathrm{~kg} \mathrm{~N} \mathrm{ha}^{-1}$ and lowest in $75 \mathrm{~kg} \mathrm{~N}^{-}$ ${ }^{1}$ both at 50 and at harvest. Higher grain yield $\left(5.99 \mathrm{t} \mathrm{ha}^{-1}\right)$ and cob/plant, grain/cob, seed index and $\mathrm{B}: \mathrm{C}$ ratio (1.75) were also obtained from $125 \mathrm{~kg} \mathrm{~N} \mathrm{ha}^{-1}$. Regarding time of application of $\mathrm{N}$, though treatment S1, exhibited higher plant height in the initial stage but ultimately treatment S3 recorded the better result. Higher grain yield of $5.63 \mathrm{tha}^{-1}$ and B:C ratio (1.64) was obtained with $\mathrm{N}$ applied in thrice $(1 / 2$ as basal $+1 / 4$ at 25 DAS $+1 / 4$ at 45 DAS) followed by S2.Thus it can be suggested that nitrogen level of $125 \mathrm{~kg} \mathrm{ha}^{-1}$ and applied in three growth stages ( $1 / 2$ as basal $+1 / 4$ at 25 DAS $+1 / 4$ at 45 DAS) in maize can be used for yield increase and higher profit in the Indo-Gangetic plains of eastern India.

\section{Conflict of interest}

All the authors would like to declare that there is no conflict of interest among them that could possibly arise in future.

\section{References}

Amanullah (2007) Partitioning of dry matter and grain yield potential in maize (Zea mays L.) as influenced by plant density, rate and timing of nitrogen application. International Journal of Sustainable Crop Production 2: 1-7.

Andrea KED, Otegui ME, Cirilo AG, Eyherabide G (2006) Genotypic variability in morphological and physiological traits among maize inbred lines. Crop Science 46:1266-1276.

Aulakh SG, Vashist KK, Mahal SS (2013) Effect of different irrigation regimes and nitrogen levels on growth parameters and yield of late kharif sown maize. Crop Research 45: 96-105.

Begam A, Adhikary S, Roy DC, Ray M (2018) Grain Yield of Kharif Maize Hybrid (Zea mays L) as Influenced by Doses and Split Application of Nitrogen. International Journal of Current Microbiology and Applied Sciences 7: 2121-2129.

Bundy LG (2006) Side dressing nitrogen: useful on all soils? In. Proceedings of the 2006 Wisconsin Fertilizer, Aglime \& Pest Management Conference 45: 39-43.

FAO (2018) Part-3: Feeding the World, Statistical Year Book of FAO of United Nation, Available on http://www.fao.org/docrep/018/ i3107e/i3107e03.pdf, accessed on 09.11.2018

Gahlout B, Singh R, Lal GM (2010) Effect of levels of nitrogen and Sulphur on growth and yield of maize (Zea mays L). Journal of Maharastra Agriculture University 35: 149-151.

Gomez KA, Gomez AA (1984)Statistical Procedures for Agricultural Research. International Rice Research Institute, John Willey and Sons, New York Pp 139-240.

Harikrishna BL, Das GS, Patil PL (2005) Effect of soil depths, Ndoses and its split application on maize plant height, LAI and dry 
matter yield at different growth stages. Karnataka Journal of Agriculture Sciences 18: 364-69

Haque MM, Hamid A, Bhuiyan NI (2001) Nutrient uptake and productivity as affected by nitrogen and potassium application levels in maize/sweet potato intercropping system. Korean Journal Crop Science 46:1-5.

James McCann (2001) Maize and Grace: History, Corn, and Africa's New Landscapes, 1500- 1999. In: Comparative Studies in Society and History: Vol. 43, No. 2, (C2001.

Joshi A, Gupta J K, Choudhary S K, Mujalde S, Garg M (2014). Effect of nitrogen sources, doses and split applications on yield and economics of maize (Zea mays L.) in the Malwa region of Madhya Pradesh (India). Journal of Agriculture and Veterinary Sciences 7: 24-28.

Kaur A (2016) Effect of different planting methods and nitrogen levels on the growth, yield and Quality of kharif maize (Zea mays L.) M.Sc. thesis, submitted to Department of Agronomy, College of Agriculture, Punjab Agricultural University Pp. 68-69.

Kaur J (2013) Spring maize (Zea maysL.) productivity as influenced by nitrogen in relation to irrigation regimes and planting methods. M.Sc. Thesis, Department of Agronomy, Punjab Agricultural University, Ludhiana.

Kumar A (2009) Production and nitrogen use efficiency of sweet corn as influenced by different planting densities and nitrogen levels. Indian Journal agriculture Science79: 351-5.

Muniswamy S, Rami Gowda, Rajendra Prasad S (2007) Effect of spacing and fertilizer levels on seed yield and quality of maize single cross hybrid PEMH-2. Mysore Journal Agriculture Science 41:186-90.
Pandey AK, PrakashVed, Mani VP, Singh RD (2010) Effect of rate of nitrogen and time of application on yield and economics of baby corn (Zea mays L.). Indian Journal of Agronomy 45: 338-343.

Parija B (2011) Performance of kharif maize under different levels of farmyard manure and nitrogen. M.Sc. Thesis, Department of Agronomy, Punjab Agricultural University, Ludhiana.

Plessis JD (2003) Adaptation and production potential, In. Maize Production, Publication by Department of Agriculture, Republic of South Africa, Pretoria 0001 Pp 10-25

Ray M, Chatterjee S, Prwinterik M, Mani PK, Roy K, Sengupta K (2009) Diversification of rice-based cropping system and their impact on energy utilization and system production. Journal of Crop and Weed 5: 167-170.

Ray M, Roy DC, Nandi AK (2014) Crop sequences vis-à-vis irrigation water related problems and mitigation: An overview of West Bengal emphasizing Gangetic flood plain. Indian Groundwater 3: 61-70

Sahoo SC, Mahapatra PK (2014) Response of sweet corn (Zea mays) to nitrogen levels and plant population. Indian Journal Agricultural Science 74: 337-338.

Singh SD (2011) Effect of irrigation regimes and nitrogen levels on growth, yield and quality of baby corn. Madras Agriculture Journal 88:367-370.

Thakur DR, Sharma V (2009) Effect of varying rates of nitrogen and its schedule of split application in baby corn (Zea mays). Indian Journal Agricultural Science 69: 93-95. 